\title{
Corpus
}

Archivos virtuales de la alteridad americana

Vol 2, No 2 | 2012

Julio / Diciembre 2012

\section{Memoria visual en el Perú: las fotografías del caso Uchuraccay}

Visual memory in Perú: Photographs of the case Uchuraccay

\section{Lizbeth Arenas Fernández}

\section{(2) OpenEdition}

Journals

\section{Electronic version}

URL: http://journals.openedition.org/corpusarchivos/804

DOI: 10.4000/corpusarchivos.804

ISSN: 1853-8037

\section{Publisher}

Diego Escolar

\section{Electronic reference}

Lizbeth Arenas Fernández, "Memoria visual en el Perú: las fotografías del caso Uchuraccay », Corpus [En línea], Vol 2, No 2 | 2012, Publicado el 30 diciembre 2012, consultado el 30 abril 2019. URL : http:// journals.openedition.org/corpusarchivos/804 ; DOI : 10.4000/corpusarchivos.804

This text was automatically generated on 30 April 2019

Licencia Creative Commons: Atribución-NoComercial 2.5 Argentina (CC BY-NC 2.5 AR) 


\title{
Memoria visual en el Perú: las fotografías del caso Uchuraccay
}

Visual memory in Perú: Photographs of the case Uchuraccay

\author{
Lizbeth Arenas Fernández
}

\section{EDITOR'S NOTE}

Fecha de recepción del original: 29/03/2012. Fecha de aceptación para publicación:

$01 / 11 / 2012$

“...las fotografías han sentado las bases sobre las
que se juzgan y recuerdan los conflictos

importantes.

El museo de la memoria es ya sobre todo visual. Las

fotografías ejercen un poder incomparable

en determinar lo que recordamos de los acontecimientos

(...)". Susan Sontag, Revista Ñ, 29 mayo 2004

1 Uchuraccay es, no sólo por su repercusión mediática sino también por la controversia que envolvió a su investigación, uno de los casos más emblemáticos de la etapa trágica que vivió el Perú durante los años 1980 al 2000. Sin embargo, veintinueve años después de lo ocurrido aún persiste la controversia sobre esta historia.

2 La Comisión de la Verdad y Reconciliación (CVR $)^{1}$, entidad encargada de investigar los hechos y responsabilidades del caso Uchuraccay así como de otros crímenes cometidos durante el período de violencia política en el Perú (1980-2000), estima que durante esa etapa murieron y/o desaparecieron 69.280 personas. Según esta institución, "la causa inmediata y fundamental del desencadenamiento del conflicto armado interno fue la decisión del Partido Comunista Sendero Luminoso (PCP-SL) de iniciar una guerra popular contra el Estado peruano" (CVR, 2003, p. 56). Indica que esta denominada guerra interna se inicia el 17 de mayo de 1980, luego del ataque senderista a una sede electoral ubicada en la localidad de Chuschi, al norte del departamento de Ayacucho, en la sierra peruana. 
Los miembros de Sendero Luminoso se autodefinían como marxistas-leninistas-maoístas y actuaron en el Perú bajo el liderazgo de Abimael Guzmán.

3 A la par de su investigación sobre los crímenes de ese período, la CVR convocó a un grupo de fotógrafos y colaboradores para la recopilación, selección y edición de unas 1700 imágenes provenientes de unos 80 archivos fotográficos a nivel nacional, los mismos que comprendieron archivos privados, de medios de comunicación, de agencias de noticias, de las Fuerzas Armadas y Policiales, instituciones de Derechos Humanos, vicariatos y álbumes familiares, que conforman actualmente el le-gado de la memoria visual sobre esa etapa. Como resultado de esta recopilación, la Comisión publicó el libro Yuyanapaq Para Recordar ${ }^{2}$ que fue además el anexo visual de su Informe Final (2003) y es el soporte en el cual se incluyeron las fotos de la masacre de Uchuraccay. Asimismo, se armó una exposición con el mismo nombre que se encuentra actualmente en el Museo de la Nación en Lima.

4 En su Informe Final, la CVR dedicó no sólo algunas páginas dando cuenta de los resultados de sus indagaciones sobre la masacre de Uchuraccay, sino también las fotografías producidas la madrugada del 26 de enero de 1983 por el reportero Willy Retto, asesinado junto a siete periodistas, un guía y un comunero mientras cubrían información sobre una matanza contra senderistas ocurrida unos días antes en las cercanías de esa misma comunidad.

5 Estas imágenes, halladas días después de los asesina-tos y publicadas veinte años después de lo ocurrido en el relato visual de la CVR, a simple vista no cumplen con los parámetros planteados para el resto de las 104 imágenes que se incluyen en el libro. En Yuyanapaq prevalecen sobre todo las fotografías en blanco y negro, con fuerte impacto visual, que están acompañadas por epígrafes con una tipografía que se asemeja a la utilizada en la prensa gráfica. Asimismo, en esta publicación se ha evitado presentar fotografías de cadáveres o imágenes sumamente violentas que pudieran herir la sensibilidad del espectador (aunque vale señalar que esta restricción fue válida para algunas víctimas, puesto que algunas fotografías de cadáveres se utilizaron para mostrar a algunos guerrilleros caídos). Sin embargo, las fotos de Retto son presentadas en secuencia (la mayor parte de las fotos en el libro fueron publicadas individualmente), están a color (la mayoría está en blanco y negro), presentan las huellas o fallas dejadas durante su tránsito por las distintas instancias militares, judiciales, familiares (a diferencia de las otras fotografías que están prolijamente presentadas sin las marcas que pudieran haber tenido en su recorrido desde los archivos hasta el libro) y, sobre todo, plantean un "modo de ver" (Berger, 2000) particular que refuerza la idea de la fotografía como testimonio de uno de los acontecimientos más emblemáticos del período de violencia en el Perú.

6 La disposición en el libro de esta serie compuesta por nueve imágenes, el aparente poco cuidado en su presentación conjunta que mantiene los colores verdosos que significan una marca en el tiempo debido a los hongos del material encontrado, y lo enigmático de lo que ahí se representa, responden a un criterio en el que se rompe con el estilo propuesto a lo largo del relato de la CVR donde se priorizaron sobre todo las imágenes individuales y bicromáticas. Estas fotografías, más que representar la violencia -como señalaría una de las editoras de Yuyanapaq- son un testimonio de la violencia misma en los precisos momentos en que ésta ocurre.

7 El hallazgo de las imágenes de Willy Retto luego de la masacre posibilitó además la existencia de diversas versiones acerca de los autores de los asesinatos. Por ello, a partir de este material intentaremos analizar el uso de la fotografía en la construcción de la 
memoria visual sobre lo ocurrido en Uchuraccay. En ese sentido, su pertenencia al Informe Final de la CVR nos obliga a analizarlas también entendiendo que las fotografías deben ser interpretadas como una textualidad, como parte de un documento oficial de la memoria y "como otra forma posible de relato, pero que entra en diálogo y establece relaciones con el texto escrito del que forma parte" (Crenzel, 2009, p. 282). En ese sentido, en tanto material simbólico, analizaremos el modo en que estas imágenes fueron constituyéndose en testimonio de lo ocurrido.

\section{Lo que ha sido}

La madrugada del 26 de enero de 1983, los periodistas llegaron a Uchuraccay a confirmar las versiones que circulaban en la prensa limeña respecto de las muertes de supuestos miembros del PCP-SL, presuntamente asesinados por los campesinos de la localidad de Huaychao, ubicada al norte de esa comunidad. Esta respuesta colectiva de los pobladores en contra del accionar de Sendero Luminoso había merecido incluso la felicitación del Presidente de la República de ese entonces, Fernando Belaúnde, por tratarse -según afirmó- de un "ejemplo de patriotismo" (CVR, 2003, p. 95).

Según el Informe de la CVR, los periodistas llegaron al poblado acompañados por el guía Juan Argumedo quien se había ofrecido a acercarlos al lugar debido a que conocía la zona y también a uno de los periodistas, Octavio Infante, quien era su medio hermano. Toda la provincia de Ayacucho era considerada por el gobierno de turno como zona de emergencia desde el año 1981, por los atentados que iban ocurriendo desde inicios de los años 80. En ese contexto, el fotoperiodista y sus compañeros llegaron al lugar y fueron confundidos -según se cree- con "terroristas" (calificación utilizada para nombrar a los militantes de los grupos armados).

10 Las semanas anteriores a los asesinatos, los Sinchis -el comando especial antisubversivo de las Fuerzas Armadas (Guardia Civil) conocido por su importante presencia represiva en las zonas del interior del país durante las décadas del 80 y 90- habían indicado a los comuneros que debían matar a toda aquella persona que llegase a su poblado a pie, puesto que esta gente vestida de civil podrían ser "terroristas", mientras que los mili-tares y policías siempre llegarían, según les indicaron, por helicóptero.

Los periodistas efectivamente llegaron a pie a Uchuraccay. En ese momento "convulsionado", los comuneros se encontraban reunidos planeando estrategias para la lucha contra Sendero Luminoso.

"La matanza fue cruel y no duró más que treinta minutos. Esa misma noche mataron al guía Juan Argumedo y a Seve-rino Huáscar Morales. A este último, por su vínculo con el PCP Sendero Luminoso, lo responsabilizaron por defender a los periodistas y al guía, acusándolo de haberlos traído en abierto desacato a las decisiones adoptadas por la comunidad" (CVR, 2003, p. 97). Así murieron los periodistas Eduardo de la Piniella, Pedro Sánchez y Félix Gavilán de El Diario de Marka, Jorge Luis Mendívil y Willy Retto de El Observador, Jorge Sedano de La República, Amador García de la revista Oiga y Octavio Infante del diario Noticias de Ayacucho, el guía Juan Argumedo y el comunero uchuraccaíno Severino Huáscar Morales" (CVR, 2003, p. 135).

A raíz de la gravedad de estos hechos y a la repercusión en la prensa, pocos días después, el gobierno conformó una Comisión Investigadora presidida por el escritor Mario Vargas Llosa; por el decano del Colegio de Periodistas del Perú, Mario Castro Arenas, y por el jurista Abraham Guzmán Figueroa. En una asamblea realizada con traductores, ya que 
ninguno de los integrantes hablaba el quechua (idioma materno de los comuneros), los campesinos habrían reconocido haber cometido los crímenes autorizados por los Sinchis para matar a los "terroristas" y callaron los asesinatos del guía y del comunero muertos ese mismo día. Del mismo modo, los pobladores pidieron a la Comisión mayor protección y presencia de los Sinchis por temor a represalias por las muertes, pero no obtuvieron atención a su pedido. De ahí en adelante, el Comando Político Militar bloqueó el acceso a la prensa a las zonas rurales y dificultó las investigaciones posteriores, incluso hasta llevar el caso a foja cero luego de dos años de investigación (Cuya, 1996, p. 34).

A los pocos días de la matanza de los periodistas, por su parte, Sendero Luminoso ingresó al poblado y asesinó a todos los comuneros que supuestamente habían participado en el ataque. De ese modo, los pobladores sufrieron los ataques tanto de senderistas como también de las Fuerzas Armadas.

"Uchuraccay fue visitada en varias ocasiones, por estar ubicada en dirección al nevado Rasuwillca, que se había convertido en una base del PCP-SL desde donde las columnas atacaban los pueblos. Muchas veces estos rastrillajes eran acciones conjuntas entre las rondas campesinas y los militares, que se convirtieron en violentas incursiones punitivas contra los uchuraccaínos. Este último capítulo comenzó apenas unos días después del ataque navideño del PCP Sendero Luminoso, cuando los militares ingresaron al pueblo, ensañándose con los sobrevivientes" (CVR, 2003,p. 105).

14 Las Fuerzas Armadas ingresaron al poblado cometiendo robos, violaciones en contra de las mujeres, asesinatos en contra de los pobladores que eran acusados de ser terroristas (CVR, 2003, p. 145). El resto de los pobladores tuvieron que huir de la zona por temor a ser asesinados. Según cifras de la Comisión Lerner, murieron 135 personas en una comunidad que en 1981 tenía 470 habitantes.

En los meses que siguieron, tal como queda sentado en el acta de incautación recopilada por la CVR, el 14 de mayo de 1983, al realizarse un patrullaje de búsqueda ordenado por el juez Juan Flores Rojas, fue hallado un maletín oculto en una pequeña cueva del cerro Raccraccasa, el cual contenía varios rollos fotográficos y los documentos personales de Willy Retto, Amador García y Pedro Sánchez. Fue hallada también una cámara fotográfica marca Minolta perteneciente a Willy Retto, "la cual contenía un rollo con nueve fotos que captan los momentos previos a la matanza" (CVR, 2003, p. 150).

Respecto a estos sucesos, la primera Comisión Investigadora de los Sucesos de Uchuraccay presentó su informe al Presidente Belaúnde en el año 1984, el cual -según Cuya- excluyó la participación de los miembros de las Fuerzas Armadas y del gobierno en la matanza, centrando la atención en la "ignorancia"3 de los campesinos (1996, p. 32). Por otra parte, la Comisión de la Verdad y Reconciliación reafirma esta exclusión de responsabilidad de las Fuerzas Armadas en este documento, en su Informe Final: "la Comisión [Vargas Llosa] concluyó que dicha incitación [militar] no fue sistemática, ni respondió a una política implementada por el Comando Político Militar, excluyendo de esa manera a los altos mandos militares de cualquier responsabilidad" (CVR, 2003, p. 50)4. Se determinó entonces que los culpables de los asesinatos habían sido tres comuneros de Uchuraccay, y que presumiblemente habían actuado con la ayuda de campesinos de otros poblados sin que existiera participación directa alguna de las fuerzas del orden.

En el Informe Vargas Llosa -según la CVR- se señalaba además que las muertes fueron resultado de "un malentendido generado por las diferencias culturales existentes entre los campesinos quechuas y el país urbano". Mario Vargas Llosa enfatizó que Uchuraccay 
era parte de un mundo completamente diferenciado del resto del país, congelado en el tiempo, "atrasado y tan violento", con hombres que viven "todavía como en los tiempos pre-hispánicos" (CVR, 2003, p. 151). Se atribuyeron también motivos mágico-religiosos a los asesina-tos por las mismas circunstancias de diferencia cultural. Esta versión permaneció por mucho tiempo en el imaginario social y se creyó por eso mismo que los asesinatos habían sido cometidos en defensa propia ante los supuestos terroristas, sin previo diálogo, puesto que los campesinos habrían creído que las cámaras fotográficas eran armas. Al respecto, Mario Vargas Llosa tras enterarse del hallazgo de las fotografías de Willy Retto en mayo de 1983, reafirmó al diario El País de España que dichas imágenes "demostraban" que las fuerzas del orden (entiéndase el Ejército, La Marina y otras Fuerzas Armadas) no tuvieron participación en los asesinatos, ya que en ellas se veía claramente a los campesinos junto a los periodistas. Y concluyó que dichos asesinatos fueron realizados por los propios comuneros (Yuste, 1983). Según la CVR, sin embargo, la suposición de que no hubo diálogo era falsa "como queda demostrado también en las fotografías de Willy Retto":

El silencio de los comuneros respecto del modo de ejecución de la masacre, motivado por su afán de ocultar la muerte del guía Juan Argumedo y del comunero Severino Huáscar Morales, impidió a la Comisión [Vargas Llosa] llegar a establecer los pormenores de lo ocurrido el 26 de ene-ro, por lo cual el informe supuso, con "convicción relativa", que los periodistas "debieron ser atacados de improviso, masivamente, sin que mediara un diálogo previo". Posteriormente, el hallazgo de las fotografías tomadas por Willy Retto demostró que dicha suposición era falsa, lo cual, para diversos sectores de la opinión pública, desacreditó el conjunto del informe, a pesar de que éste precisaba líneas abajo que "no se puede descartar, tampoco, que este intento de diálogo se produjera y fuese inútil debido al exceso de suspicacias, pánico y furor de los comuneros o a alguna imprudencia o error en el curso de la conversación por par-te de los periodistas que agravase el malentendido en vez de disiparlo" (CVR, 2003, p. 150).

A partir del hallazgo de estas imágenes meses después de la masacre, se manejaron diversas versiones acerca de los autores de los asesinatos. Por un lado, según la vestimenta y el modo en que se encontraban los personajes en las tomas, algunos familiares de las víctimas y un sector de la sociedad sostuvieron que las muertes habían sido producidas por miembros del Comando Militar denominado Sinchis y no únicamente por los campesinos. Discursos similares sirvieron a los diarios, algunos de los cuales perdieron a sus propios periodistas en la matanza y fueron quienes difundieron las primeras noticias dando a conocer la participación de los Sinchis en la masacre (IMAGEN N - 1). Esta sospecha los llevó incluso a reclamar investigaciones y justicia para el caso, ya que a través de las imágenes se evidenciaba para ellos la participación de los militares en dicha masacre. En las fotografías se lograría ver a otros personajes con vestimenta "occidental" y relojes que indicarían la presencia de miembros de las Fuerzas Armadas en el lugar y en el momento de los asesinatos. Por otro lado, el propio Vargas Llosa señaló que estas fotografías confirmaban justamente lo contrario, "que los reporteros fueron asesinados por los campesinos, sin que participaran en el crimen fuerzas del orden" (Yuste, 1983). Ponciano Del Pino (2003) señala respecto del uso de estas fotos por parte de los familiares:

Sobre las fotos de Willy Retto hay que decir que sirvieron de referente para construir diversas interpretaciones sobre la matanza. De hecho, eran la única evidencia "objetiva" de esos sucesos. Así las familias de los periodistas, al observar algunos cuerpos de mayor tamaño y objetos como pantalones de fábrica, reloj, anillo, creyeron encontrar en ellas evidencia de la participación en la matanza de 
los Sinchis, disfrazados con ponchos de campesinos. Eso se repitió el año 2001, cuando el fotógrafo Oscar Retto, padre de Willy Retto, como parte de las celebraciones por el 26 de enero, viajó con otros familiares de los periodistas desde Lima hasta Uchuraccay e hizo en Ayacucho una exposición de las fotos de su hijo. Analizando el contenido de las fotos, mostró esos objetos que alteraban la "armonía" andina como evidencia segura de que no sólo los campesinos habían tenido participación en la matanza. Eso ha permitido también, para estos familiares, mantener sus demandas de justicia y sanción a los responsables (p. 76).

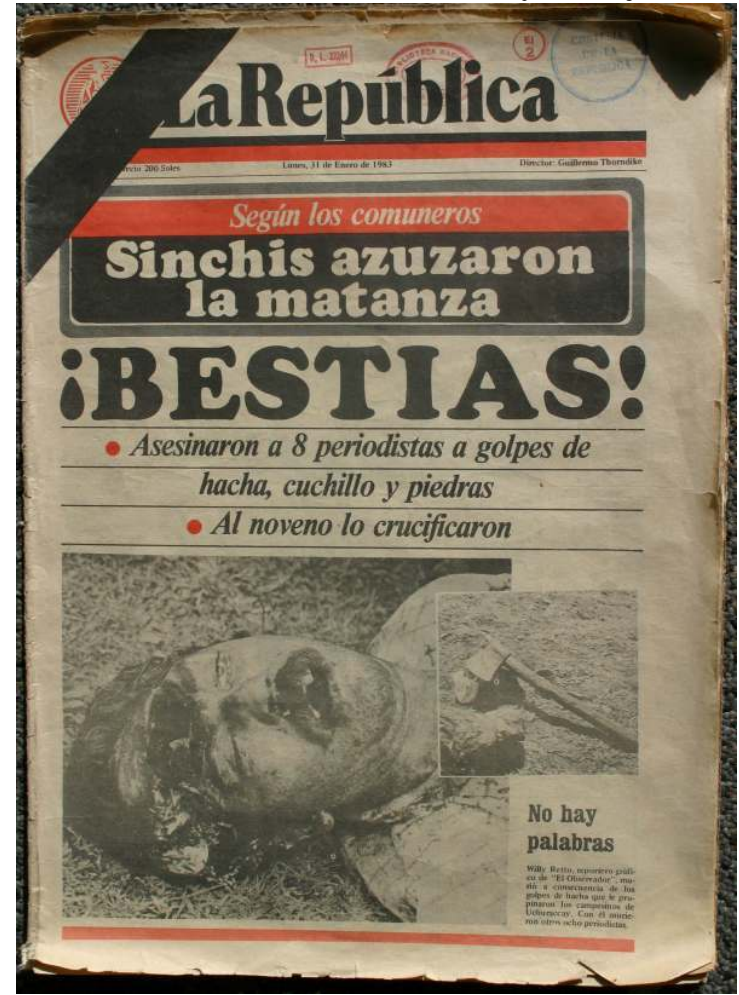

Imagen № 1. Diario La República del 30 de enero de 1983 dando cuenta de la versión sobre la participación de los Sinchis en la matanza. Fuente: Biblioteca Nacional del Perú.

Los diferentes sentidos con los que se cargan estas imágenes en su tránsito hasta llegar al libro de la CVR, dan cuenta del uso de la fotografía como un dispositivo social, político y jurídico. Sus usos determinaron sus sentidos. El modo en que estas imágenes son utilizadas, visibilizadas y puestas en escena en este contexto histórico extremo y de construcción de memoria, permitiría esbozar el modo en que la sociedad peruana percibe a la fotografía. Asimismo, permite observar el modo en que se reconstruye con ellas la memoria de un suceso traumático y las luchas que existen alrededor del sentido de su mensaje. Las fotos de Uchuraccay, en ese marco, son un ejemplo de ese transitar simbólico de la imagen en tanto testimonio y en tanto dispositivo utilizado por las distintas memorias en pugna.

\section{Lo que miramos}

El contenido del rollo fotográfico tomado por Willy Retto permaneció latente en el imaginario social y alejado del debate público por varios años hasta el momento en que su padre, el fotógrafo Oscar Retto, entregó ese material al equipo fotográfico de la CVR. La difusión del conjunto del relato permitió el retorno de estas imágenes a la escena pública 
después de más de veinte años, reavivando así las diversas memorias y las diversas narraciones sobre esos acontecimientos. ${ }^{5}$

Según Nancy Chapell, editora y curadora del re-lato visual de la CVR, Retto padre había encontrado copias de las mismas en las fojas del caso en el Poder Judicial en Lima y realizó de manera clandestina las reproducciones de las fotos ya ampliadas en papel. Un tiempo después, las fotos halladas en el Poder Judicial se perdieron y hasta el momento se desconoce su paradero, al igual que el resto de los rollos encontrados durante las primeras investigaciones. Oscar Retto guardó, sin embargo, esos nuevos negativos en la guantera de su auto. A raíz de las indagaciones del equipo fotográfico de la CVR, se supo que estas reproducciones estaban aún en manos de Oscar Retto y se logró recuperar el mate-rial. Los negativos fueron encontrados con hongos por la humedad y el calor del espacio de guarda. Chapell, quien además fue la encargada directa de la recuperación de este material, señala sobre este hallazgo:

(...) las originales se perdieron en el Poder Judicial y el papá de Willy Retto, fue alguna vez al Poder Judicial y a escondidas fotografió, antes que se perdieran, las fotos de los expedientes. Por eso tienen los sellos del Poder Judicial, en algunas se nota, aquí esta la grampita oxidada también de los expedientes. Cuando yo he ido a entrevistar al señor, él tenía los negativos de estas reproducciones y los tenía en la guantera de su Volkswagen, ahí los tiene así no se les pierde y ahí los tenía, entonces esto ya es reproducción de la reproducción (...) eso ya no lo quisimos retocar porque ya es un testimonio, porque las fotos originales se per-dieron en el Poder Judicial en los expedientes, entonces nos pareció que era así, es como es, es lo que hay y así se queda y el retoque para estas fotos fue básicamente para sacarle la cantidad de hongos que tenía y todos estos colores verdosos y mal calibrados son tal cual... (Chapell, 2007).

En las fotografías de Retto se ve muy poco. Al menos, resulta difícil a simple vista dar una conclusión respecto de lo que ahí se presenta. Para un espectador desprevenido, estas imágenes pueden resultar incluso un conjunto de fotografías mal tomadas. Los personajes que ahí aparecen retratados están por lo general de espaldas, sus rostros son poco distinguibles y las imágenes tampoco "dicen" mucho sobre el lugar de los asesinatos y sobre el acto de violencia que dicen reflejar. En ellas no se ven armas, ataques, enfrentamientos o indicios que puedan dar cuenta de la violencia ${ }^{6}$ en los precisos momentos en que esta ocurre. En ellas sólo se ven algunas tomas desenfocadas con algunas personas difícilmente identificables a simple vista, en pose de estar conversando. Objetos como los maletines que estas personas llevaban consigo, campesinos que al parecer bajan de una de las laderas de los cerros a dar encuentro a los foráneos (que son identificados por la diferencia en la vestimenta respecto a los otros), a alguien con campera azul que está arrodillado pero a quien no se le ve el rostro, otro sujeto de espaldas, y otros que están a su lado de pie; parte del paisaje y una última toma que parece mostrar una parte del rostro de quien fotografía. 


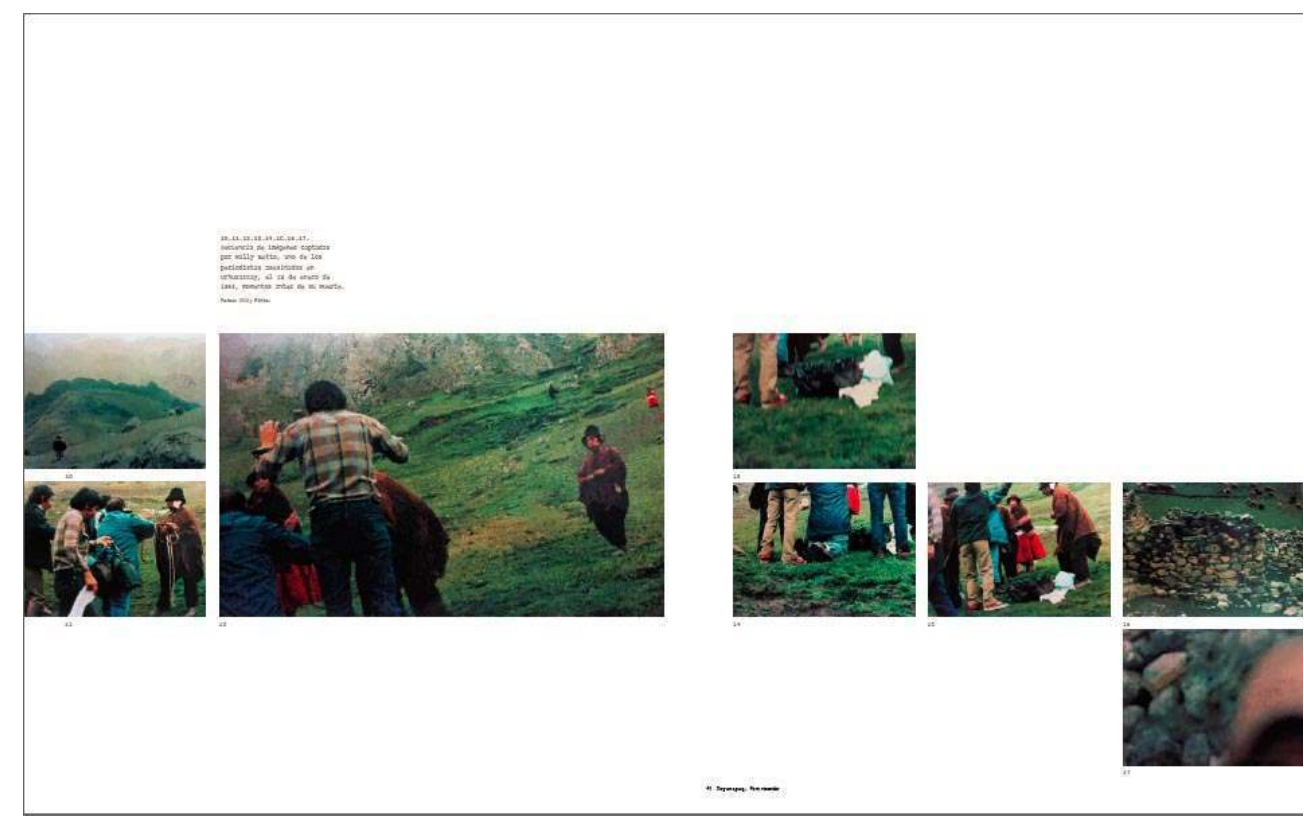

Imagen No 2. Serie fotográfica de nueve imágenes tomadas por Willy Retto el 26 de enero de 1983, publicadas en las páginas de Yuyanapaq: Para Recordar. Fuente: Comisión de la Verdad y Reconciliación.

Las preguntas que surgen entonces son ¿por qué estas imágenes que aparentemente no muestran nada claro constituyen una prueba de la violencia? ¿Qué sucede con estas fotografías para que los distintos grupos y sectores involucrados las utilizaran para sustentar sus memorias personales y sociales? ¿Por qué se las consideró como pruebas "objetivas" de lo acontecido? Y ¿qué sentidos se le cargaron a estas imágenes para ser en la actualidad evidencia y testimonio visual de ese acontecimiento traumático?

En principio, las fotos de Retto son las únicas imágenes que existen (o se conocen) de ese suceso. Por lo tanto, serían las únicas "pruebas" de lo que ahí ocurrió. Sin duda, esta característica resulta importante para entender la "objetividad" que recae sobre ellas.

A partir de ahí existen dos aspectos que sustentan la verosimilitud de estas imágenes: las fotografías son consideradas como testimonio de muerte y como pruebas judiciales. Ambos aspectos se complementan al momento de publicarse en el relato visual además como "documentos contundentes" y son los que a su vez sostienen fuertemente la verosimilitud de estas fotografías como material de memoria.

En primer lugar, la serie fotográfica es presentada como testimonio de muerte. En ese sentido, la violencia resulta ser el asesinato, la muerte misma, que precisamente no se ve. En ella el fotógrafo es a la vez testigo y es víctima. Se trata del último registro visual del reportero antes de morir y como tal se constituye en mirada testigo de lo sucedido, pues no sólo se trata de un testigo directo sino además de un periodista en el cumplimiento de sus funciones. Sin duda, la muerte le agrega valor al testimonio, pues ante un hecho así parafraseando a Ariés- "la sola idea de la muerte conmueve" (2000, p. 56). Ellas son un "doble documento histórico por aquello que muestran del pasado y por lo que nos informan de su autor y de las determinaciones históricas, sociales y políticas que subyacen a su estética de la representación" (Crenzel, 2009, p. 283).

La serie de Uchuraccay está cargada además de sentido temporal: fueron tomadas en el "mismo momento" que ocurrían los asesinatos. Hubo un cuerpo ante la muerte para que estas imágenes existieran. El cuerpo que sujetaba la cámara captó un instante preciso, el 
"momento decisivo" tan valorado en el fotoperiodismo. Se trata de un testimonio y también de un documento. Ello resulta valioso en la reconstrucción de los hechos si se tiene además un único material visual como aval, si el testimonio es directamente ese material fotográfico, entonces la evidencia se torna indiscutible, sobre todo si ellas "funcionan allí como prueba de existencias humanas interrumpidas" (Da Silva, 2009, p. 359).

En estas fotografías también resulta atrapante "este nuevo punctum, que no está ya en la forma, sino que es de intensidad, es el tiempo, es el desgarrador énfasis del noema 'esto ha sido', su representación pura. (...)". Barthes señalaba: "Yo leo al mismo tiempo: esto será y esto ha sido; observo horrorizado un futuro anterior en el que lo que se ventila es la muerte. (...) la fotografía me expresa la muerte en futuro" (2006, p. 146). En ese aspecto, las fotografías de Retto son ese preciso instante, ellas registran la anticipación de la muerte y es ahí donde radica su potencia como testimonio de violencia.

Estas fotografías se perciben también como "objetivas"; es decir, como resultado de la mirada de un foto-periodista (poseedor de una supuesta objetividad periodística) y de una mirada mediada por la cámara (por un medio mecánico) que supuestamente no deja espacio para la intervención subjetiva del fotógrafo. Son "objetivas" por su fuerza evidenciadora. En relación a ello, vale señalar que en el periodismo las imágenes tomadas con ese fin se perciben como neutrales y objetivas, aunque esas huellas, en sí mismas, como señala Jelin, no constituyen memoria a menos que sean evocadas y ubicadas en un marco que les dé sentido (2001, p. 30). A su vez, la creencia de la no intervención subjetiva del fotógrafo en la elaboración de la imagen (ya que es producida por un medio mecánico que es la cámara fotográfica) borra de algún modo el punto de vista, el lugar y la posición desde la cual se hace la toma, reforzándose así esa supuesta no intervención en los acontecimientos registrados y, por lo tanto, lo que se obtiene de ese proceso serían imágenes directas de lo que realmente sucedió. En ese sentido, existe la expectativa de que estas fotos representen real y fidedignamente los horrores causados (Zelizer, 2000, p. 249), percibiéndoselas por ello como documentos reales.

Ellas además son las únicas imágenes que existen sobre ese hecho en el mismo instante en que este crimen ocurre. El testigo calificado e indiscutible por su condición de periodista, de fotógrafo y además de víctima, registra en imágenes los hechos ocurridos y éstas se constituyen en evidencia. La muerte posterior, sin duda, suma a esta valorización porque se trata ahora de la mirada de un héroe ${ }^{8}$.

31 Estaríamos entonces frente a un fotógrafo/víctima no pasivo. El fotógrafo estaba armado efectivamente. El poder de sus disparos aunque no mataron, generaron imágenes que violentaron (simbólicamente) después también a una sociedad adormecida que desconocía hasta ese momento lo que iba ocurriendo.

La cámara/arma no mata, así que la ominosa metáfora parece un mero alarde, como la fantasía masculina de tener un fusil, cuchillo o herramienta entre las piernas. No obstante, hay algo depredador en la acción de hacer una foto. Fotografiar personas es violarlas, pues se las ve como jamás se ven a sí mismas, se las conoce como nunca pueden conocerse; transforma a las personas en objetos que pueden ser poseídos simbólicamente. Así como la cámara es una sublimación del arma, fotografiar a alguien es cometer un asesinato sublimado, un asesinato blando, digno de una época triste, atemorizada (Sontag, 2006, p. 30).

32 Llama la atención, por eso mismo, la comparación entre la cámara y el arma que algunos sectores intentaron instalar aduciendo que era producto de la ignorancia de los campesinos. Esta versión contemplaba la idea de que los comuneros habían reaccionado 
de manera violenta ante los periodistas al creer que las cámaras de los reporteros eran armas, atribuyéndoles esa visión a su condición de "indios". Este argumento fue planteado justamente por uno de los altos miembros de las Fuerzas Armadas, el general Clemente Noel, que era jefe del Comando Político Militar de Ayacucho en el momento de la masacre y uno de los sospechados por los familiares de participar en dicho crimen (CVR, 2003, p. 140). En ese aspecto, atribuir a la cámara fotográfica una función de maquinaria para matar resulta más que llamativo.

Con esta serie luego de su difusión en el libro de la CVR lo que interesó fue, por un lado, centrar la mirada en la figura de los periodistas asesinados durante el desarrollo de su trabajo y también en la muerte de un testigo directo. Por otra parte, desde el punto de vista jurídico, a poco de encontrarse este rollo fotográfico -en una cueva y entre las piedras, como señala el Informe- las imágenes sirvieron como prueba para las instancias judiciales que las incluyeron como material relevante para sus investigaciones?. Las fotografías de Willy Retto constituyeron, bajo esa primera estructura de "objetividad", una prueba. La ecuación fotografía = verdad (Penhos, 2005, p. 19) se manifiesta en este nivel, puesto que pasan a ser para la justicia una prueba de lo sucedido. Y lo que interesa - a decir de Feld (2000) - es que de algún modo la justicia escribe la historia. Entonces no se trata sólo de imágenes que documentan un testimonio, fotografías periodísticas cargadas de objetividad por esa misma condición, sino que pasan a ser también un indicio para la justicia. En esta instancia es además la justicia la que las sustenta como prueba.

En el informe publicado por la CVR sobre este caso, se da cuenta del uso de estas imágenes como pruebas judiciales. En la sentencia dictada por el Tribunal Especial emitida el 9 de marzo de 1987 por el cual se acusa a los tres campesinos de ser culpables de los asesinatos, el juez declara comprobada la presencia militar y policial en Uchuraccay el día de la masacre considerando cuatro indicios, dos de los cuales se basan en las fotografías de Retto:

a) la visita regular de patrullas a las comunidades; b) las fotografías de Willy Retto que mostrarían una persona con pantalón de material diferente al usado en el atuendo tradicional, con zapatos y un porte distinto; c) la presencia de personal encubierto reconocido por el uso de relojes y sortijas; d) las declaraciones de Juana Lidia Argumedo sobre la presencia de un joven extraño el día de su detención, el cual hablaba castellano, usaba reloj, encendedor y tenía autoridad sobre el resto de los comuneros (CVR, 2003, p. 166).

Más allá de los cuestionamientos posteriores que se hicieron sobre si estos indicios basados en las fotos eran fehacientes o no, lo que vale resaltar es que estas fotografías fueron utilizadas por la justicia como elemento probatorio y sirvieron, en su momento, para dictar sentencia a los campesinos acusados del crimen.

En consecuencia, existe una condición que marca la serie de Uchuraccay. Antes de ser dadas a conocer a la prensa, las imágenes de Retto ya contaban con el verosímil otorgado además por la justicia.

Por lo tanto, estas imágenes son valoradas no sólo por su relación con el referente o por su carácter de huella sino principalmente por los diferentes usos que se le dieron desde su hallazgo. Su fuerte repercusión en el imaginario social peruano en tanto material de memoria respecto a esta matanza está dada precisamente por esa condición probatoria. En este caso, lo que se recuerda de estos sucesos depende de los sentidos que ellas fue-ron obteniendo hasta llegar al libro de la CVR. A partir de ahí, las fotos de Uchuraccay -que 
ya venían con esa carga de verosimilitud, como lo señalamos anteriormente- se suman al objetivo de la CVR de garantizar "la verdad"10. Es en este nivel donde puede observarse la real función que cumplen estas fotografías en la construcción de la memoria sobre Uchuraccay. Las imágenes de Retto generan conmoción, muestran desolación ${ }^{11}$, evidencian la vulnerabilidad de las víctimas, sirvieron incluso para manifestar las discusiones acerca de las distancias culturales existentes en el Perú, pero sobre todo muestran una lucha de sentidos que contribuyó a que este conjunto sea usado para corroborar las versiones incluso más disímiles entre ellas. Precisamente porque en ellas no se ve la violencia.

El uso dado por las distintas instancias marca también el sentido final que estas fotografías adquieren en la memoria visual sobre ese hecho veinte años después de lo ocurrido. A decir de Burke, "las fotografías no son nunca un testimonio de la historia: ellas mismas son algo histórico" (Burke, 2001, p. 28). Y, en esa perspectiva, los sentidos de la serie dependen de sus usos sociales a lo largo de estos años.

Para la familia, las fotografías de Retto servían como evidencia para demostrar que los periodistas habían sido asesinados por instigación del comando Sinchis que actuaba en la zona, muchas veces - como se demostró años después- también asesinando, silenciando y torturando a los que eran sospechosos de apoyar a la guerrilla.

41 Por otra parte, existe en los propios campesinos de Uchuraccay una "doble memoria" radicada tanto en el espacio privado como en el espacio público como miembros de esa comunidad. Del Pino (2003) concluye que "uno encuentra así dos versiones de la misma gente respecto a la matanza de los periodistas: una historia 'oculta', sedimentada en la memoria privada de cada persona, pero capaz de reconocer los detalles más mínimos de la matanza, y una historia para el consumo del mercado, prefabricada, repetitiva y reconstruida permanentemente para cada interlocutor" (p. 81). Así, estas fotografías sirvieron para la construcción de las distintas memorias: la de los familiares, la de la prensa, la de la Comisión Vargas Llosa, la de la propia CVR e incluso la de los campesinos de Uchuraccay ${ }^{12}$. Sus sentidos dependieron del contexto y de la coyuntura política que las fue utilizando de acuerdo a las necesidades de argumentos.

42 En la etapa post conflicto, las fotografías de Retto ocupan las páginas 40 y 41 del relato visual Yuyanapaq. El epígrafe que las acompaña indica: "Secuencia de imágenes captada por Willy Retto, uno de los periodistas asesinados en Uchuraccay, el 26 de enero de 1983, momentos antes de su muerte". Su puesta en página presenta las nueve imágenes en forma de secuencia, planteando en sí mismo un relato sobre este hecho. Las fotos están a color y resaltan en medio de un corpus donde predomina el blanco y negro ${ }^{13}$. En tanto que el color predominante sobre la serie de Uchuraccay, casi en forma pareja, es el verde. Esto -como señalaba anteriormente la curadora- se debió a los hongos que se encontraban sobre los negativos debido a la humedad y el calor del lugar de guarda. Entonces se decidió mantener estas "fallas" como marcas del paso del tiempo y de su tránsito por las distintas instancias. Marcas que, en definitiva, intentan plasmar también la violencia simbólica que sufrieron estas fotografías a lo largo de su recorrido. Así se mantuvieron las huellas de los sellos y grapas que sujetaban las fotos en papel encontradas en las fojas del caso en el Poder Judicial y el color provocado por la humedad de la guantera del auto. Por lo tanto, tal como lo indica la editora, se ha procurado mantener esos rasgos con las reproducciones de estas fotos - del tiempo, hongos, color de los negativos, las grapas- a fin de hacer perdurar el testimonio manifiesto en estas imágenes. Debido a la pérdida de los originales, las reproducciones realizadas por el padre del fotógrafo asesinado se 
constituyen a su vez en prueba de esa desaparición y de su tránsito por los distintos niveles en las que fueron utilizadas. Esa característica creemos refuerza en gran medida su valor probatorio y testimonial.

Mantener las fotos tal cual fueron encontradas (aclaremos nuevamente que se trata ya de la reproducción de esas tomas) se suma al movimiento que ya existe en estos registros. Asimismo, esa apariencia de fotografías mal tomadas y desenfoque que muestran algunas de ellas les suman credibilidad, ya que, como afirma Sontag, las imágenes borrosas se perciben como más verídicas (Sontag, 2006). Por ello, todos estos vestigios del recorrido que sufrieron las fotos durante esa época han sido conservados como huellas que permiten reafirmar el carácter de documento y de evidencia atribuido a esta serie.

Por otro lado, se debe tomar en cuenta que estas fotografías forman parte de un Informe Final Visual en el cual se ha considerado a la fotografía como "prueba" y "documento incuestionable". En la justificación del proyecto presentado por las coordinadoras del equipo fotográfico encargadas de la recopilación de estos registros, se contemplaron distintos soportes de difusión de las imágenes partiendo de considerar a la fotografía periodística ${ }^{14}$ como un material de "absoluta credibilidad" y como una "prueba innegable" de lo ocurrido, por lo que en la propuesta fotográfica a la que se le denominó inicialmente bajo el nombre de "Casa de la Verdad", se planteaba:

(...) la fotografía periodística desde sus inicios ha sido entendida como 'prueba' o 'testimonio' de un hecho real. Cuando miramos una imagen publicada en un diario, no nos queda duda de que el hecho que estamos mirando sí ocurrió. Podríamos decir entonces que, en un primer nivel, el proyecto fotográfico mostrará ante un público estas pruebas y su lectura de credibilidad será absoluta e incuestionable. ${ }^{15}$

Y Chapell agrega al respecto sobre el carácter de la fotografía:

(...) si nos preguntas a Mayu y a mí, de hecho también te diríamos que la foto es como una prueba innegable ¿no? Ahora hay gente que te dice sí pero la foto no es objetiva o no sé qué. No, no es objetiva desde el punto de vista de que yo puedo arrodillarme para hacer la foto y tú la haces parada, la puedes hacer en blanco y negro o color. De hecho cada fotógrafo tiene su punto de vista, pero o sea de que esto pasó, más allá de que tú lo tomes de acá y yo de allá, pasó. O sea de que estas personas existieron, de que este pueblo fue quemado, es un documento contundente ¿no? (Chapell, 2007).

De ese modo, desde el inicio del discurso de la CVR la indicialidad de la imagen se equipara con la "verdad" que muestra la fotografía. La credibilidad o "verdad" a priori atribuida a la fotografía se sustenta así en su carácter de signo indicial que permite que la curaduría la presente como "huella de lo real" (Dubois, 1994: 42). Y una de las características de la fotografía en tanto index es precisa-mente la de atestiguar la existencia de una realidad. Pero este aspecto es lo que les posibilita también argumentar el trabajo y los criterios de edición, pues por el propio estatuto de la fotografía en tanto "indicio" (Dubois, 1994; Schaeffer, 1990) existe la tendencia inevitable de que los discursos visuales construidos en base a fotografías se conviertan en materiales legitimados y legitimizadores de una verdad indiscutible sobre esos procesos históricos, tal como se intenta plasmar en este relato.

En ese aspecto, las nueve imágenes que conforman la serie de Uchuraccay son, en ese marco, difundidas como "pruebas" de los acontecimientos. Es decir, hubo un criterio de elección y de presentación de las imágenes para que su carácter probatorio se vea reforzado. La serie, sin embargo, no muestra más de lo que el epígrafe y el contexto que las enmarca puedan decir. La violencia es dicha más que vista. El epígrafe y las imágenes 
en conjunto conforman un discurso sobre la matanza, y lo que interesa -como señala Zelizer (2000) respecto a las imágenes de mujeres en el Holocausto- es cómo esta serie reduce a pocas imágenes (y un texto) lo que se debe recordar visualmente acerca de este suceso. En esta serie "cuando las palabras fallan, puede entrar en escena una imagen, y cuando las imágenes resultan opacas, las palabras pueden revelar un significado oculto o un significado complejo" (Huyssen, 2009, p. 17). En consecuencia, los dos elementos (texto e imagen) se constituyen mutuamente conformando un discurso sobre la memoria del hecho que se sostiene en una verosimilitud construida desde sus usos sociales. Si bien el texto da sentido y torna relevante la serie (aparentemente conformada por imágenes movidas y mal tomadas), son las imágenes las que terminan de dar sentido a "la violencia" referida en el epígrafe (imágenes realizadas por Willy Retto minutos antes de ser asesinado) y, en conjunto, conforman una serie verosímil que se torna incuestionable y verdadera. Se presenta así un "anclaje" entre la función del epígrafe con respecto a la foto, es decir una relación entre el texto y la imagen que es ideológica y que "acomoda la mirada y la intelección" de quien las ve. Tal como señala Barthes, "con respecto a la libertad de significación de la imagen, el texto toma un valor represor, y es comprensible que sea sobre todo en el texto donde la sociedad imponga su moral y su ideología" (Barthes, 1987, p. 37).

Precisamente, en el uso de estas fotografías se revelan las distintas posturas políticas con las que se afrontó e interpretó el caso en los distintos niveles de la sociedad peruana, hasta llegar al Informe Final de la CVR donde la moral y la ideología están, en principio, en poder del Estado.

En este caso, las fotografías toman niveles de verosimilitud que marcan una distinción respecto de las otras imágenes del relato de la CVR. Las fotografías más próximas que anteceden a esta serie también se refieren a este suceso. Sin embargo, estas fotos al ser anteriores y posteriores a los hechos no ocupan el mismo nivel que los registros de Retto. Las fotos antecedentes se presentan en blanco y negro. La primera imagen vinculada al tema (ubicada en la página 38), pertenece a Oscar Infante (otro de los periodistas asesinados) (IMAGEN № 3). Esta imagen fue elaborada unas horas antes de ocurrida la matanza. En ella se ve el retrato de siete de los periodistas posando para la cámara en una de las vías que los conduciría a Uchuraccay. El epígrafe indica: "Periodistas Jorge Sedano, Amador García, Luis Mendívil, Félix Gavilán, Pedro Sánchez, Willy Retto y Edmundo de la Piniella antes de perecer en la masacre de Uchuraccay. El autor de la foto es Oscar Infante, otra de las víctimas". Otra fotografía acompaña a esta imagen, en la página 39 (IMAGEN N ${ }^{\circ}$ 3). En ella ya se presentan en blanco y negro los cuerpos sin vida de los periodistas momentos después de ser desenterrados. Sus cuerpos permanecen junto a las fosas precarias en las que habían sido sepultados. Esta imagen ocupa un mayor tamaño frente a la foto de los periodistas retratados aún vivos. La leyenda señala: "Exhumación de los restos de los ocho periodistas asesinados en Uchuraccay, Ayacucho, el 26 de enero de 1983. Ellos habían viajado a las punas de Huanta a investigar el levantamiento de los campesinos contra Sendero Luminoso. Foto: Diario Oficial El Peruano". 


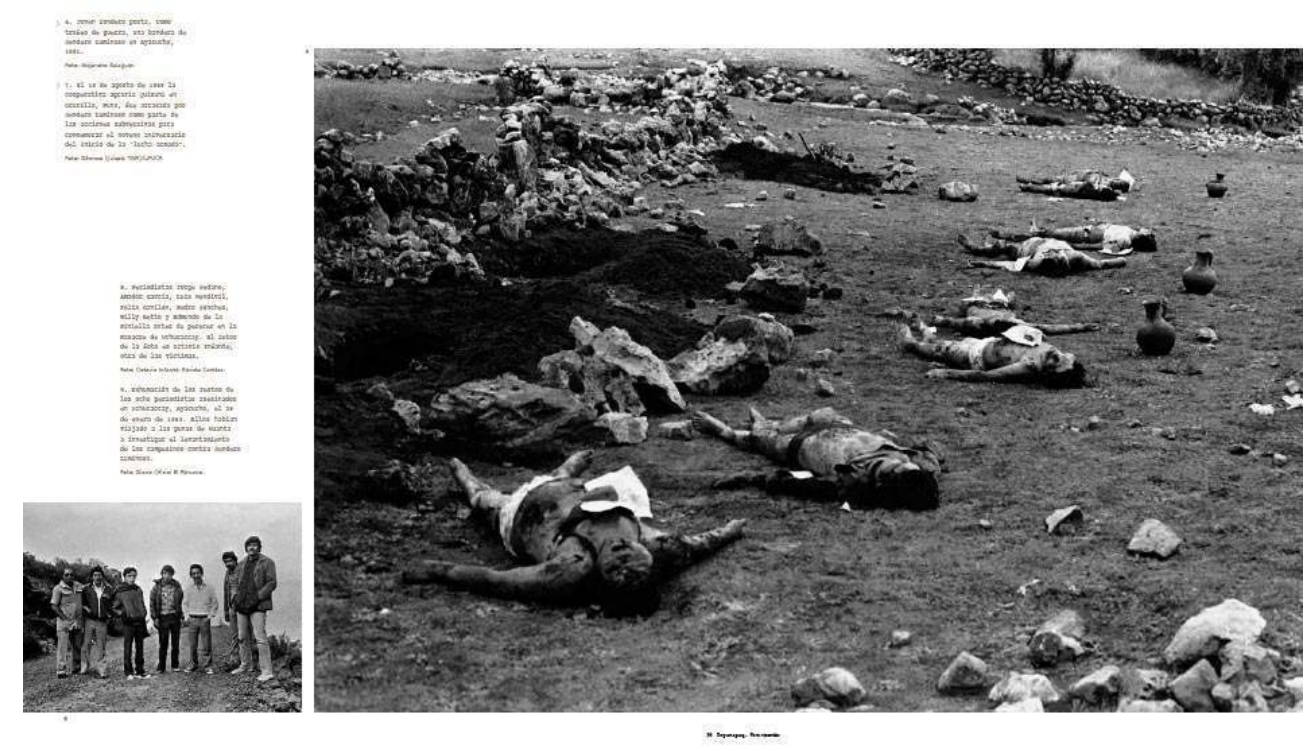

Imagen $N^{\circ}$ 3. Fotografías de los periodistas asesinados en Uchuraccay, toma-das por Octavio Infante (Revista Caretas) y el Diario Oficial El Peruano, publicadas en las páginas de Yuyanapaq: Para Recordar. Fuente: Comisión de la Verdad y Reconciliación.

El relato de Uchuraccay está conformado entonces por un antes (los periodistas vivos), un después (la muerte y los cuerpos de las víctimas) y el instante preciso (las imágenes de Retto). El antes y el después se presentan en blanco y negro y el instante preciso está a color. $Y$ entre el antes y el después lo que tiene más relevancia sin duda es el después, son los cuerpos, la muerte consumada. Esto no resulta llamativo en ese contexto, pues en todo el relato lo que prevalece es un discurso que intenta mostrar las consecuencias de la "guerra" ${ }^{16}$. Los cuerpos se presentan en mayor tamaño, ocupan gran parte del diseño de página, es la evidencia de que la violencia existió, es la muerte que está ahí. Con estas fotos se complementa la "muerte" que no muestra la serie de Retto.

51 En este caso interesan además los sentidos que la Comisión de la Verdad y Reconciliación otorgó a es-tas fotografías, puesto que ellas forman parte de un relato fotográfico que conforma la memoria visual de la etapa más trágica que vivió el Perú durante el siglo XX. La CVR recuperó la serie $y$, sin desconocer las versiones disímiles que se le atribuyeron a lo largo del tiempo, las publicó, pero esta vez centrándose en la muerte. Ya que el discurso general del relato busca homenajear a las víctimas de la violencia política, esta serie es presentada precisamente como el máximo testimonio de esos hechos $\mathrm{y}$, por ende, el máximo documento de una víctima inocente y heroica de la guerra. Si antes la serie sirvió para avalar los discursos más acordes al informe de la Comisión Vargas Llosa o sirvió para las demandas de justicia de los familiares de los asesinados, esta vez en Yuyanapaq, la serie representa también el testimonio de la figura de la víctima y es un documento de la violencia ocurrida en esos años. Son esas tomas fotográficas borrosas y desenfocadas las que complementan el texto de victimización que se ha construido respecto del conflicto interno porque se trata justamente de las fotografías del momento exacto en que ocurren los hechos ${ }^{17}$.

Sin embargo, los sentidos no están dados única-mente por los textos que acompañan la imagen o la relación existente entre imagen-texto, sino sobre todo por los discursos que circularon alrededor de esta serie. En ese aspecto, respecto de la idea de que estas 
imágenes sirvieron para evidenciar "las distancias y brechas culturales" esgrimidas por algunos sectores - como lo señalamos anteriormente-, Poole y Rojas (2010) brindan una lectura actual a partir del análisis de la exposición Yuyanapaq sobre el uso de estas fotos como evidencia de esas diferencias y el modo en que las fotografías de Uchuraccay marcaron un antecedente en la circulación de las imágenes en los años siguientes:

Lo que choca aquí es cómo los "significados" de las fotografías pueden ser descifrados solamente porque la narrativa de los acontecimientos se daba por sabida. Estos "significados" adquieren la fuerza de la verdad, pero a través de una carga afectiva que emerge sólo por el miedo a un "otro" cultural peligroso, en una problemática posición de sujeto, desde la cual, se les solicitaba a los peruanos que examinaran esta evidencia de "malententendidos culturales", los que supuestamente alimentaban la violencia en Perú.

Al investir las fotografías con el poder de actuar como testigo, y usando esta fuerza evidenciadora para canalizar las emociones intangibles del miedo y de la alteridad, el caso Uchuraccay fijó dos precedentes importantes sobre cómo las imágenes fotográficas circularían en la violencia de los años siguientes. Por una parte, Uchuraccay marcó la inherente inestabilidad -y desconfianza- de la imagen fotográfica. De hecho, la guerra se extendió, el valor de evidencia de las fotografías de Retto cambió de lugar drásticamente. En un contexto donde la expansión geográfica de la guerra hizo cada vez más difícil hablar de una separación entre las montañas y el resto de la nación, las fotografías dejaron de ser un soporte para el "abismo" espacial e histórico que separaba Uchuraccay de la nación-estado. En cambio, su carácter de evidencia impulsó una búsqueda cada vez más intensa de signos sobre el rol esta-tal en la vida de los campesinos... (Poole y Rojas, 2010).

La serie fotográfica de Willy Retto plantea, en ese aspecto y luego de formar parte de un Informe Final, un modo de recordar este suceso. Las múltiples memorias se cierran en una, la que indica que fueron los campesinos los que tuvieron la responsabilidad absoluta en los asesinatos. Según lo que señala el Informe Final, fueron los campesinos los que asesinaron a los periodistas. Del Pino (2003) afirma al respecto: "No hay duda de que ellos lo hicieron" (p. 77).

Por todo lo señalado anteriormente, las fotografías de Retto empiezan a conformarse como el testimonio de muerte y, por ende, de la violencia sufrida. No se habla aquí sólo de lo que las imágenes presentan, puesto que esta calificación de las fotografías como testimonio se inician precisamente antes, desde la verosimilitud también otorgada al personaje que realiza las tomas y las condiciones que anteceden las fotografías incluso antes de que aparezcan a la vista de los investigadores. Se trata de fotografías percibidas como verídicas en la cultura visual y sobre todo son, en esta cultura, prueba de lo que le ocurrió a la sociedad. Al tratarse de las imágenes de los mismos momentos en que la muerte ocurre, estas fotos adquieren otro valor frente a las demás. Y, en esa perspectiva, las fotografías de Uchuraccay y del conjunto de Yuyanapaq cumplen un rol relevante en la constitución de las memorias (o del intento de construir una única Memoria).

Poole y Rojas no sólo esgrimen sobre el cambio de sentidos que adquirieron estas fotografías a partir de su uso sino, desde un primer momento, señalan que ellas sirvieron para sustentar la teoría del "abismo" cultural y cómo los nuevos sentidos se centraron después en cuestionar el rol del Estado respecto de la vida de esas poblaciones.

Para el Estado peruano es imprescindible centrar en las víctimas su discurso sobre este conflicto, pues ello le permite deslindar su responsabilidad en todos los hechos ocurridos durante esos veinte años y aún en la actualidad. El Estado tuvo grandes responsabilidades en esta etapa, ya sea por el accionar de sus Fuerzas Armadas o por su descuido a estas 
zonas pauperizadas. Si bien el gobierno bajo el cual se hizo esta investigación no fue el mismo que participó en esos años, es cierto también que sigue siendo el Estado quien maneja esa memoria. En este caso, resaltar la figura de ciertas víctimas más que otras también son un indicativo del modo en que el Estado percibe a los ciudadanos: unos son más válidos que otros. Veamos si no, por ejemplo, por qué cuando se menciona el caso Uchuraccay se habla siempre de los ocho periodistas y se olvida mencionar los asesinatos del guía y el comunero, ambos pertenecientes a las cercanías de esos poblados.

Actualmente en el Perú se construye un Museo de la Memoria ${ }^{18}$ para recordar los sucesos de esa etapa y cuyo espacio iba a ser dirigido en un principio - propuesto no casualmente por el gobierno de Alan García, agente de la represión de esos años- por el escritor Mario Vargas Llosa. Actualmente se construye el "Lugar de la Memoria, la Tolerancia y la Exclusión Social" cuya implementación está cargo de una comisión de alto nivel presidida por Diego García-Sayán. Habría que preguntarse entonces ¿qué otros sentidos se le otorgarán a es-tas fotografías? ¿la serie visual de Uchuraccay se usará una vez más para confirmar responsabilidades o reafirmar culpabilidades? En nuestro caso -acordando con Baer- "el referente histórico ya no es el acontecimiento, sino su representación, es decir las fotografías (...). Todo es un déjà vu. Pero visto no en la realidad, sino en la imagen" (Baer, 2006, p. 132).

Sin duda, serán las imágenes las que prevalecerán en las memorias. Las fotografías recopiladas por la CVR son publicadas una y otra vez en todos los medios de comunicación cada vez que se conmemora a las víctimas y se discute sobre los sucesos de esta etapa. Existe en Lima una muestra permanente conformada por muchas de las fotografías que integran el libro y todo material gráfico referido al tema ilustra sus páginas con estas imágenes. Son las fotografías las que se constituyen como íconos y son sin duda las que finalmente narrarán para la posteridad la memoria de la violencia política en el Perú.

\section{BIBLIOGRAPHY}

Arenas Fernández, L. (2008). Ojos Opacos. Una indagación sobre la figura de la víctima en el relato fotográfico de la Comisión de la Verdad y Reconciliación del Perú. Revista de Antropología Visual, 12. Obtenido el 15 de marzo de 2011 desde: http://www.antropologiavisual.cl/arenas.htm

Arenas Fernández, L. (2009). Cuanto más cerca, más lejos. Las víctimas en las fotografías de violencia de la Comisión de la Verdad y Reconciliación. Ponencia presentada para el Congreso de Latin American Studies Association (LASA). Obtenido el 15 marzo de 2012 desde: http:// lasa.international.pitt.edu/members/con-gress-papers/lasa2009/files/ArenasLizbeth.pdf

Arenas Fernández, L. (2011). Vengan todos a ver. jAy vamos a ver! Los usos políticos de la fotografía sobre la violencia política en el Perú (1980-1992). Tesis de Maestría no publicada, Universidad de Buenos Aires, Facultad de Ciencias Sociales, Argentina

Ariès, P. (2000) La muerte del otro y La muerte prohibida. En P. Ariès, Morir en Occidente (pp. 53-86). Buenos Aires: Adriana Hidalgo. 
Baer, A. (2006). El cine y la televisión: el horror en la pantalla. En A. Baer, Holocausto. Recuerdo y representación

(pp. 111-145). Madrid: Losada.

Baeza, P. (2001). Por una función crítica de la fotografía de prensa. Barcelona: Ed. G. Gilli.

Barthes, Roland (1987). “Mensaje fotográfico" y "Retórica de la Imagen”. En Lo Obvio y lo obtuso. Buenos Aires: Paidós.

Barthes, R. (2006). La Cámara Lúcida. Buenos Aires: Paidós.

Berger, J. (2000): Modos de ver. Barcelona: Gustavo Gili.

Burke, P. (2001) Visto y no visto: El uso de la imagen como documento histórico. Barcelona: Editorial Crítica.

Chapell, N. (2007, abril 7). Entrevista personal realiza-da por la autora a la curadora y editora de Yuyanapaq: Para Recordar. Manuscrito. Lima, Perú.

Comisión de la Verdad y Reconciliación (2003). El Caso Uchuraccay. En Informe Final (Tomo VCapítulo 2). Obtenido el 03 de agosto de 2008 de: www.cverdad. org.pe

Comisión de la Verdad y Reconciliación (2003). Informe Final. Obtenido el 03 de agosto de 2008 de: www.cverdad.org.pe

Crenzel, E. (2009). Las fotografías del Nunca Más: ver-dad y prueba jurídica de las desapariciones. En C. Feld y J. Stites Mor (Comps.), El Pasado que miramos.

Memoria e Imagen ante la historia reciente (pp. 281-313). Buenos Aires: Paidós.

Cuya, E. (1996). Comisiones de la Verdad en América Latina. En KO’AGA ROÑE’ETA se.iii. Artículo originalmente publicado en la Revista Memoria, de Dokumentations und Informationszentrum Menschenrechte in Lateinamerika. Obtenido el 14 de julio de 2009 de: http://www.derechos.org/ koaga/iii/1/cuya.html

Da Silva Catela, L. (2009). Lo invisible revelado. El uso de fotografías como (re) presentación de la desaparición de personas en la Argentina. En C. Feld y J. Stites Mor (Comps.), El Pasado que miramos. Memoria e Imagen ante la historia reciente (pp. 337-361). Buenos Aires: Paidós.

Del Pino, P. (2003). Uchuraccay: memoria y representación de la violencia política de los Andes. En C. I. Degregori (Ed.), Jamás tan cerca arremetió lo lejos. Memoria y violencia política en el Perú (pp. 49-93). Lima: Instituto de Estudios Peruanos / Social Science Research Council.

Dubois, P. (1994). El Acto Fotográfico. De la Representación a la Recepción. Barcelona: Paidós.

Feld, C. (2000, diciembre). El duelo es imposible y necesario. Entrevista con Henry Rousso. En Revista Puentes, 1(2) (30-39).

Huyssen, A. (2009). Medios y Memoria. Prólogo. En C. Feld y J. Stites Mor (Comps.), El Pasado que miramos.

Memoria e Imagen ante la historia reciente (pp.15-24). Buenos Aires: Paidós.

Jelin, E. (2001). Los Trabajos de la Memoria. España: Siglo XXI.

Ledo, M. (1998). Documentalismo fotográfico. Madrid: Ediciones Cátedra.

Lerner, S. (2002). Discurso inaugural presentado por el Presidente de la Comisión de la Verdad y Reconciliación, Salomón Lerner, el 10 de octubre de 2002 en Testigos de la Verdad. Conversatorio de Fotoperiodismo, Violencia Política y Memoria Visual. Obtenido el 16 de septiembre 2011 de: http://www.cverdad.org.pe/ apublicas/p-fotografico/discurso.php 
Penhos, M. N. (2005). Frente y Perfil. Una indagación acerca de la fotografía en las prácticas antropológicas y criminológicas en Argentina a fines del siglo XIX y principios del XX. En VIII Premio Fundación Telefónica, Arte y Antropología en la Argentina (pp. 17-64). Buenos Aires: Fundación Espigas.

Perla Anaya, J. (2002). Derecho a la intimidad, límites, hechos públicos e historia. Ponencia presentada en Testigos de la Verdad. Conversatorio de Fotoperiodismo, Violencia Política y Memoria Visual, octubre, Lima. Obtenido el 27 de enero 2006 de: www.cverdad. org.pe

Poole, D. y Rojas, I. (2010). Memorias de la reconciliación: Fotografía y memoria en el Perú de la posguerra. En Emisférica 7.2. After Truth - Detrás/después de la verdad, revista del Hemispheric Institute of Performance and Politics: New York University. Obtenido el 12 de diciembre de 2011 desde: http://hemi.nyu.edu/ hemi/es/e-misferica-72/poolerojas http://hemi.nyu. edu/hemi/es/ e-misferica-72/poolerojas

Schaeffer, Jean-Marie (1990). La imagen precaria/Del dispositivo fotográfico. Madrid: Ediciones Cátedra. Signo e Imagen.

Sontag, S. (2006). Sobre la Fotografía. Buenos Aires: Alfaguara.

Sontag, S. (2004, mayo 29) Imágenes torturadas. En Re-vista Ñ, 6-9.

Theidon, K. y Peralta Quinteros, E. (2003, febrero). Uchuraccay: La política de la muerte en el Perú. En Ideele. Revista del Instituto de Defensa Legal, 269, 27-31.

Vilches, L. (1993). Teoría de la imagen periodística. Barcelona: Editorial Paidós.

Yuste, J.G. (1983, mayo 25). Vargas Llosa defiende su in-forme sobre el asesinato de ocho periodistas en Ayacucho. En El País. Obtenido el 09 de septiembre de 2010, desde: http:// www.elpais.com/articulo/interna-cional/VARGAS_LLOSA/_MARIO/PERU/Vargas/Llo-sa/ defiende/informe/asesinato/periodistas/Ayacucho/ elpepiint/19830525elpepiint_7/Tes?print=1

Zelizer, B. (2000). Gender and atrocity: Women in Holocaust photographs. En Visual Culture and the Holocaust (pp. 247-271). New Brunswick, NJ: Rutgers University Press.

\section{NOTES}

1. La Comisión de la Verdad fue creada el 4 de junio de 2001, durante el gobierno transitorio de Valentín Paniagua, quien asumiera luego que el Presidente Alberto Fujimori fugara hacia el Japón, en medio de graves denuncias de corrupción. El Presidente Alejandro Toledo, tres meses después, la ratifica y complementa, conformándola finalmente como la Comisión de la Verdad y Reconciliación. Tal como se indica oficialmente, la CVR es la instancia encargada de esclarecer el proceso, los hechos ocurridos y las responsabilidades correspondientes a la época de violencia. Su deber es investigar, no sólo a quienes la ejecutaron sino también a quienes la ordenaron o toleraron, y proponer iniciativas que afirmen la paz y la reconciliación entre todos los peruanos. Yuyanapaq es una palabra quechua que significa Para Recordar, tal como indica el título en español. El título en quechua responde a la intención de los editores de vincular las imágenes a las víctimas y a un país que desconocía estos hechos traumáticos. A pesar del título en quechua, la publicación fue editada totalmente en castellano. Las cifras de víctimas estipuladas por la CVR dan cuenta de un $75 \%$ de personas pertenecientes a las comunidades quechuahablantes que fallecieron o desaparecieron en esa etapa. Para Poole y Rojas (2010), “yuyanapaq es a la vez un nombre particularmente apto para una exposición que fue creada y diseñada para provocar y mantener una memoria colectiva de la guerra que puede constituirse en la memoria nacional de 
la guerra, y un síntoma que habla de las formas sociales de ansiedad que rondan la exposición de la CVR".

2. Yuyanapaq es una palabra quechua que significa Para Recordar, tal como indica el título en español. El título en quechua responde a la intención de los editores de vincular las imágenes a las víctimas y a un país que desconocía estos hechos traumáticos. A pesar del título en quechua, la publicación fue editada totalmente en castellano. Las cifras de víctimas estipuladas por la CVR dan cuenta de un $75 \%$ de personas pertenecientes a las comunidades quechuahablantes que fallecieron o desaparecieron en esa etapa. Para Poole y Rojas (2010), “yuyanapaq es a la vez un nombre particularmente apto para una exposición que fue creada y diseñada para provocar y mantener una memoria colectiva de la guerra que puede constituirse en la memoria nacional de la guerra, y un síntoma que habla de las formas sociales de ansiedad que rondan la exposición de la CVR".

3. En este sentido, Ponciano del Pino (2003) señala también que esas calificaciones de "ignorantes" y "salvajes" les sirvió a los propios campesinos de Uchuraccay para inventar una historia que los ex-culpara de la matanza y, a su vez, saciar la sed de curiosidad con la que llegaban visitantes, periodistas e intelectuales al lugar, para conocer la "verdad de lo ocurrido" el 26 de enero de 1983.

4. Respecto del Informe de la Comisión Vargas Llosa nos limitamos a citar partes del documento reproducidos en otras fuentes, ya que no se tuvo acceso a la fuente directa.

5. Las fotografías de Retto fueron publicadas en la revista Caretas (nro. 787) en febrero de 1984. El 25 de mayo de 1984, en las páginas de El Diario, se informa sobre estas imágenes dando cuenta de la presencia militar en la matanza en el artículo titulado: "Uchuraccay. Fotos revelan rostros de los asesinos" (Del Pino, 2003, p. 76). Posteriormente el padre del fotógrafo las expuso en la provincia de Ayacucho en pos de su reclamo de justicia junto a otros familiares. Recién años después, luego de su recuperación e inclusión en el año 2003 en el relato visual Yuyanapaq: Para Recordar, de la CVR, las imágenes pasaron a ser publicadas en diversos soportes y medios de comunicación.

6. Tomamos como violencia, en este apartado, únicamente a las acciones físicas de agresión que provocaron la muerte de los visitantes. Sin embargo, no desconocemos las distintas definiciones que existen sobre violencia desde la perspectiva de las Ciencias Sociales para el análisis.

7. Fue el fotógrafo francés Henri Cartier-Bresson, considerado el padre del fotoperiodismo, quien divulgó este concepto de captura fotográfica y que fue adoptada por fotógrafos de todo el mundo. En términos generales, el momento decisivo consiste en realizar una toma fotográfica considerando todos los elementos que componen una imagen de manera que con una sola de ellas pueda comunicarse el hecho que se está cubriendo. Este concepto nos sirve en este ensayo para pensar también el rol que cumplió el fotógrafo en ese instante, su búsqueda por capturar el momento preciso.

8. Vale recordar en este punto que a los periodistas asesinados se los recuerda en la historia peruana reciente como los "mártires de Uchuraccay".

9. Recordemos que las fotografías fueron encontradas en una inspección judicial en mayo de 1983, es decir casi cuatro meses después de ocurridos los asesinatos.

10. "La Comisión de la Verdad y de la Reconciliación está obligada a 'garantizar el derecho de la sociedad a la verdad', conforme a uno de los considerandos del Decreto Supremo Nro. 065-2001PCM" (Perla Anaya, 2002).

11. El propio Presidente de la Comisión de la Verdad y Reconciliación del Perú (CVR), Salomón Lerner (2002), se refiere al legado visual de la siguiente manera: "Rostros de desolación y perplejidad ante la tragedia capturados para siempre, manos cuarteadas por el trabajo que nos muestran abiertas y desoladas la pequeña imagen del familiar desaparecido y así como ellas otras escenas que llevan todas una misma leyenda: no consentir en el olvido interesado o indiferente, escribir nuestra historia que adviene bajo el signo de un mandato moral perentorio: que el horror 
no regrese, que la memoria del dolor se vea trocada en esperanza, que la vida en el Perú transcurra bajo el signo de la solidaridad y la justicia".

12. En su estudio sobre la memoria en Uchuraccay, Kimberly Theidon y Enver Peralta Quinteros (2003) dan cuenta de los sentidos y la lucha entre memorias que también existen entre los propios campesinos de la comunidad y la comparan con la memoria predominante. Es ahí que como señalan los autores- "el racismo y la exclusión ejercen su poder, al nivel inconsciente, convirtiéndose en lo 'natural' " (p. 6).

13. La predominancia del blanco y negro en el relato visual de la CVR se debe, en principio, al tipo de negativos que necesariamente se usaban en la época. En el período en el que se plasmaron estos registros, la fotografía era impresa principalmente en blanco y negro en los medios gráficos, ya que aún los diarios no se imprimían a color. Es por eso que los fotógrafos trabajaban en su mayoría con negativos de ese tipo. A eso podría deberse también la prevalencia de imágenes bicromáticas en el relato visual. Sin embargo, en las revistas como Caretas la fotografía a color era ya utilizada desde años anteriores. Quizá ése sea el motivo por el cual Willy Retto eligió usar negativos a color para esas últimas tomas. Por su parte, en el caso del libro de la CVR, el uso del color sirvió para construir sentidos respecto a ciertos actores. Para ampliar sobre el uso del color en el libro de la CVR, puede verse: Arenas Fernández, 2008, 2009. Por su parte, la curadora de la muestra indicó que algunas fotos fueron publicadas en blanco y negro, aún cuando las originales se encontraban a color, debido a que este cambio le agregaba "mayor dramatismo" al relato.

14. Vale señalar que en este trabajo focalizamos nuestro estudio en la fotografía conocida como periodística/ documental. El fotoperiodismo es una de las formas que puede adoptar el documentalismo (Baeza, 2001 p. 41) y es -según lo indica Vilches- el tipo de fotografía que crea el acontecimiento: “Allí donde el fotógrafo decide apuntar su cámara allí nace la escena informativa. Esto es tan cierto que si cambiamos el punto de vista o la escena, cambia el acontecimiento" (1993, p. 141). En el mismo sentido, como lo indica Ledo, la fotografía periodística es una variante de la fotografía documento o la fotografía documental, que es percibida como más cercana a la realidad en tanto transparenta sus reglas en los medios de comunicación (1998, p. 13).

15. Texto incluido en la justificación del proyecto presentado por María de Fátima [Mayu] Mohanna ante la CVR. El proyecto impreso se encuentra en el Centro de Documentación de la Defensoría del Pueblo, Lima. El destacado es nuestro.

16. Para ampliar sobre este discurso victimizatorio en Yuyanapaq: Para Recordar, puede verse: Arenas Fernández (2008). Hay que señalar, en ese sentido, que el libro publicado por la CVR está dedicado precisamente a las víctimas y se ubica al Perú como una víctima más, una víctimanación. La dedicatoria indica: “A las víctimas, al Perú".

17. Para ampliar sobre los mecanismos y operaciones utilizadas por la Comisión de la Verdad en los modos de representar fotográficamente a las víctimas del conflicto, puede verse Arenas Fernández, L. (2011).

18. El Museo de la Memoria ha sido construido con la donación de dos millones de dólares que fue otorgada por el gobierno alemán al Estado peruano en el año 2009. En un inicio, este dinero fue rechazado por el Presidente de la República, Alan García, quien sin esgrimir argumentos sobre la negativa a la ayuda alemana, señaló que de aceptarse la donación ésta debía designarse únicamente a proyectos sociales. Ante la presión de la sociedad, sin embargo, debió reconsiderar el ofrecimiento. Vale señalar, que el gobierno de García fue acusado de cometer graves violaciones a los Derechos Humanos en su primer mandato en los años 1985-1990.

Entre tanto, las discusiones sobre el término "Museo" provocaron que los integrantes del espacio decidieran cambiar el nombre por "Lugar de la Memoria" y en ella se expondrán las fotografías recopiladas por la Comisión de la Verdad y Reconciliación. La construcción del lugar está en manos de la empresa privada y fue designada por concurso a los arquitectos de Barclay\&Crousse. 


\section{ABSTRACTS}

On January 26, 1983, eight journalists, a guide and a villager were killed in the village of Uchuraccay, located in the highlands of Peru, while investigating the killings committed by the Communist Party of Peru "Sendero Luminoso". One of the photojournalists killed on the spot, Willy Retto, managed to take the last images of those facts before he died. These photographs were found several months after the slaughter obtaining, from there, different meanings in their transit through the judiciary system, by researchers and family members, allowing the various versions of the murders.

In 2003, the Commission of Truth and Reconciliation recovered and published the photographs in its final report "Yuyanapaq: To Remember", which revived the struggle for the memory on those facts.

The character of "proof" that is attributed to this set of images, its publication in the visual narrative about that period and its presentation as the last living witness of the photojournalist, are interesting for analysis in the light of the proposals about photography as testimony and memory material. Uchuraccay still is for some sectors a pending and unresolved issue.

El 26 de enero de 1983, ocho periodistas, un guía y un comunero fueron asesinados en el poblado de Uchuraccay, ubicado en la sierra del Perú, mientras investigaban las matanzas cometidas por el Partido Comunista del Perú Sendero Luminoso. Uno de los fotoperiodistas asesinados en el lugar, Willy Retto, logró tomar las últimas imágenes de esos hechos antes de morir. Esas fotografías fueron encontradas muchos meses después de la masacre, obteniendo a partir de ahí, distintos sentidos en su tránsito por el poder judicial, por los investigadores y los familiares, lo que permitió las diversas versiones sobre los asesinatos.

En el 2003, la Comisión de la Verdad y Reconciliación recuperó y publicó las fotografías en su Informe Final "Yuyanapaq: Para Recordar", lo que reavivó las luchas por las memorias sobre esos hechos.

El carácter de "prueba" que se le atribuye a este conjunto de imágenes, su publicación en el relato visual sobre ese período y su presentación como el último testimonio de vida del fotoperiodista, resultan interesantes para su análisis a la luz de los planteos en torno a la fotografía como testimonio y como material de memoria. Para algunos sectores, Uchuraccay significa aún para el país un tema pendiente e irresuelto.

\section{INDEX}

Keywords: Photography, Visual memory, Perú, Uchuraccay, Political violence

Palabras claves: Fotografía, Memoria visual, Perú, Uchuraccay, Violencia política 


\section{AUTHOR}

\section{LIZBETH ARENAS FERNÁNDEZ}

Consejo Nacional de Investigaciones Científicas y Técnicas (CONICET)/Instituto de Altos Estudios Sociales (/IDAES). Investigadora del grupo UBACyT: Lugares de la mirada. Comunidad, alteridad y conflicto entre el espacio y la imagen (2010-2012). Universidad de Buenos Aires/Instituto Nacional de Antropología y Pensamiento Latinoamericano (INAPL), Argentina.). Correo electrónico: lizbetharefer@hotmail.com 